\title{
Chemical education and the pharmaceutical industry*
}

\author{
Albert E. Fischli \\ Pharmaceutical Research, F. Hoffmann-LaRoche Ltd, Grenzacherstrasse 124, \\ Building 71/502, CH3070, Basel, Switzerland
}

Abstract: The burgeoning need for molecular scientists in the pharmaceutical industry is fueled by the evolving nature of chemistry, biology, and physics, the applications of which are best assisted by an understanding of the use of informatics. The legitimate common interests of society, government, industry, and higher education systems dictate a fresh look at curricular issues associated with the training of molecular scientists, i.e. chemists. Some suggestions are offered.

An education in science starts with mathematics, nowadays, certainly joined by information technology, followed closely by the three key experimental sciences of physics, chemistry, and biology. Later on, the research dimension is added, constituting an instrument for the creation of new knowledge. The process involved is characterized by its mostly interdisciplinary nature, resulting from the expanding overlap between the basic scientific disciplines (see Figs 1-3), a rapidly growing complexity, and the

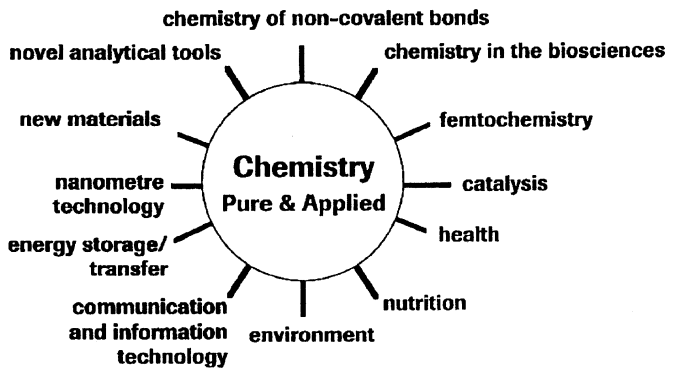

Fig. 1 Evolving chemistry.

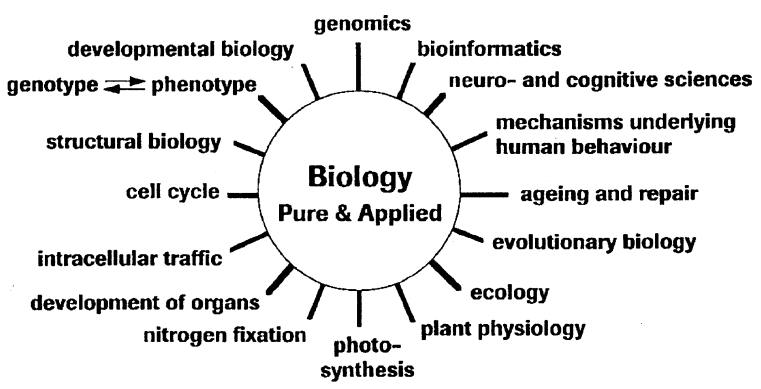

Fig. 2 Evolving biology.

\footnotetext{
*Plenary lecture presented at the 15th International Conference on Chemical Education: Chemistry and Global Environmental Change, Cairo, Egypt, 9-14 August 1998, pp. 801-870.

Correspondence: E-mail: albert.fischli@roche.com
} 
disappearing autarchy of individual laboratories. Therefore, for modern university education novel curricula need to be developed that exploit the essential unity of all sciences.

Our pleomorphic academic institutions are paralleled by very different industrial entities. Some of them are driven by innovation and others, clearly, by marketing and production. Today one of the highest R \& D budgets (Fig. 4) are encountered in the pharmaceutical industry where bioinformatics and functional genomics, combinatorial chemistry and high-throughput robotic screening are of importance, to mention only a few of the fields involved. Combinatorial approaches to chemical synthesis (Figs 5 and 6) produce a large number (Table 1) of potentially useful products. Such approaches allow for the systematic and rapid exploration and screening of chemically interesting systems. Combinatorial chemistry is of great value because it shifts the strategy from one chemist/week/compound produced to one chemist/week/10 000 compounds produced! Skilled people with solid scientific training combined with a broadly based education are needed. An idea is born in someone's brain, but the conversion of the idea into a product entails a lengthy period of team effort before the result is ready for launch on the market. One thing is very clear in industry; new knowledge, which mostly comes into being at academic institutions, is the first of a series of requirements. Only when knowledge is available can it be translated into a novel, marketable product (Fig. 7). For this reason, basic research, the funding of which is a government domain, is of primordial importance (Table 2). Challenges for emerging economies include finding ways (a) to invest in education aimed at increasing scientific awareness and communication skills of its work force (b) foster well-selected scientific areas of strategic importance to the country (vide supra) (c) create a legal framework that favors the emergence of SME's as well as collaboration with global companies, and (d) creating stimuli that encourage successful entrepreneurial activities. The relationship among stakeholders is shown in Fig. 8 and described in Table 3.

Governmental funding of education and research in molecular biology, which in fact already started in the early 19 forties, allowed the US government to lay the foundations upon which biotechnology and, from 1976 onwards, the biotech industry could be built up. After about 50 years, this up-front payment has shown a very high return on investment (Table 4). Today's US biotech industry is stable with regard to the number of companies that make it up (Table 6), but it is growing in terms of employees and sales

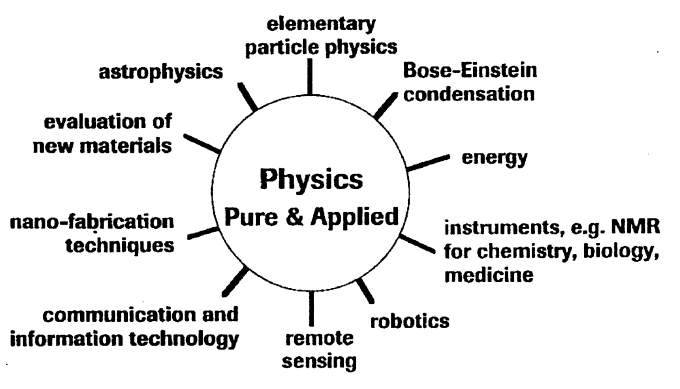

Fig. 3 Evolving physics.

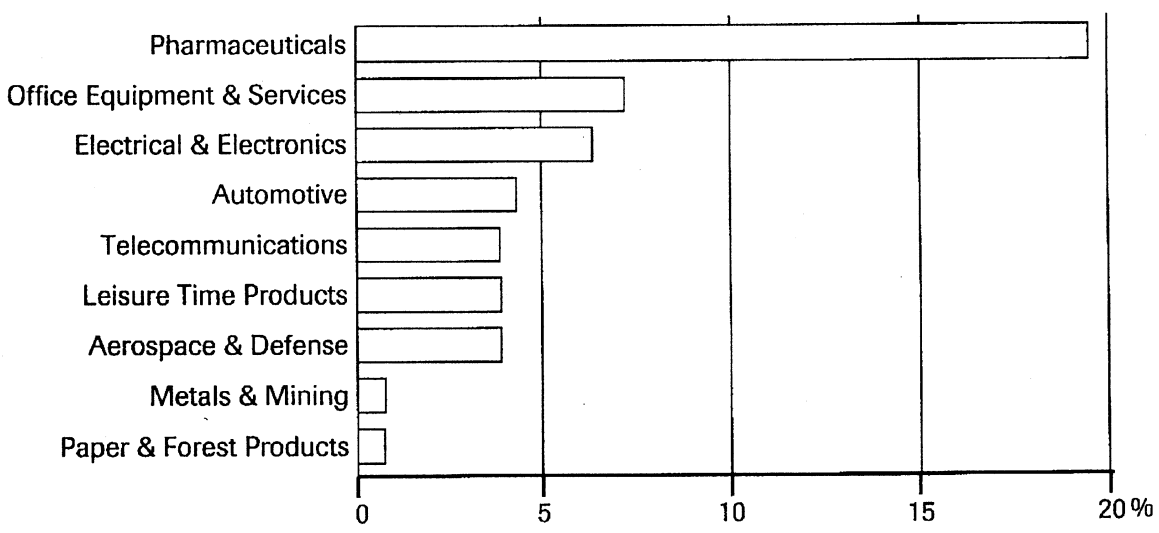

Fig. 4 R\&D as a percentage of sales in 1996. Source: [1]. 
Step 1:

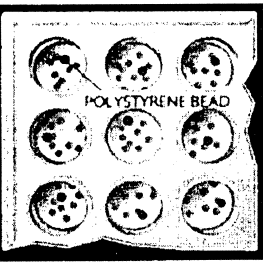

Step 3:

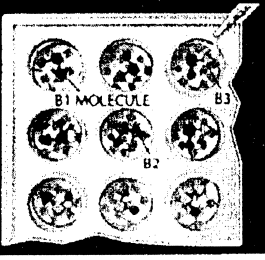

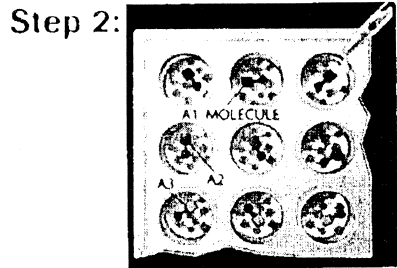

Step 4

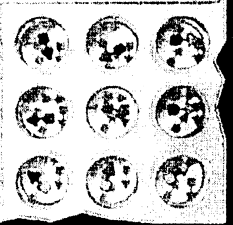

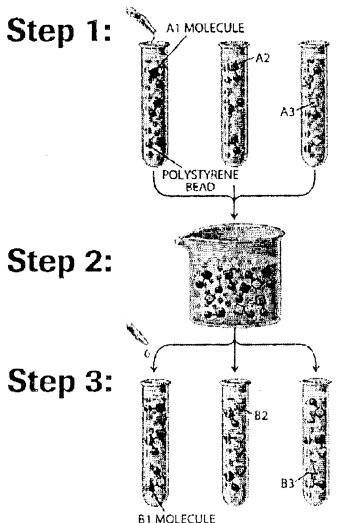

Step 4:

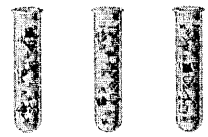

Fig. 6 A representation of the split-and-mix synthesis in combinatorial chemistry [2].

Table 1 An example of the explosion of polypeptides produced by combinatorial techniques. The complete library of 60 -mers is based on 20 amino acids, yielding $20^{60}=1.15 \times 10^{78}$ different peptides. There is not enough mass in the universe to provide for one molecule of each peptide in this theoretical synthesis

$\begin{array}{lr}1 \mathrm{H}-\mathrm{X}_{1} \mathrm{OH} & 20 \\ 2 \mathrm{H}-\mathrm{X}_{1}-\mathrm{X}_{2}-\mathrm{OH} & 400 \\ 3 \mathrm{H}-\mathrm{X}_{1}-\mathrm{X}_{2}-\mathrm{X}_{3}-\mathrm{OH} & 8000 \\ 4 \mathrm{H}-\mathrm{X}_{1}-\mathrm{X}_{2}-\mathrm{X}_{3}-\mathrm{X}_{4}-\mathrm{OH} & 160000 \\ 5 \mathrm{H}-\mathrm{X}_{1}-\mathrm{X}_{2}-\mathrm{X}_{3}-\mathrm{X}_{4}-\mathrm{X}_{5}-\mathrm{OH} & 3200000 \\ 6 \mathrm{H}-\mathrm{X}_{1}-\mathrm{X}_{2}-\mathrm{X}_{3}-\mathrm{X}_{4}-\mathrm{X}_{5}-\mathrm{X}_{6}-\mathrm{OH} & 64000000 \\ 7 \mathrm{H}-\mathrm{X}_{1}-\mathrm{X}_{2}-\mathrm{X}_{3}-\mathrm{X}_{4}-\mathrm{X}_{5}-\mathrm{X}_{6}-\mathrm{X}_{7}-\mathrm{OH} & 1280000000 \\ 8 \mathrm{H}-\mathrm{X}_{1}-\mathrm{X}_{2}-\mathrm{X}_{3}-\mathrm{X}_{4}-\mathrm{X}_{5}-\mathrm{X}_{6}-\mathrm{X}_{7}-\mathrm{X}_{8}-\mathrm{OH} & 25000000000\end{array}$

Source: [3]

(Table 4). The number of biotech companies in Europe is not far below the US figure, but most of the European companies are distinctly smaller than the American ones (Tables 5 and 6). In other words, it can be concluded that government funding of basic research and education has produced new knowledge and, subsequently, new high-tech industry. This mechanism, thus, brought about an increase in wealth, some of which flowed back to the government by fiscal pathways. 


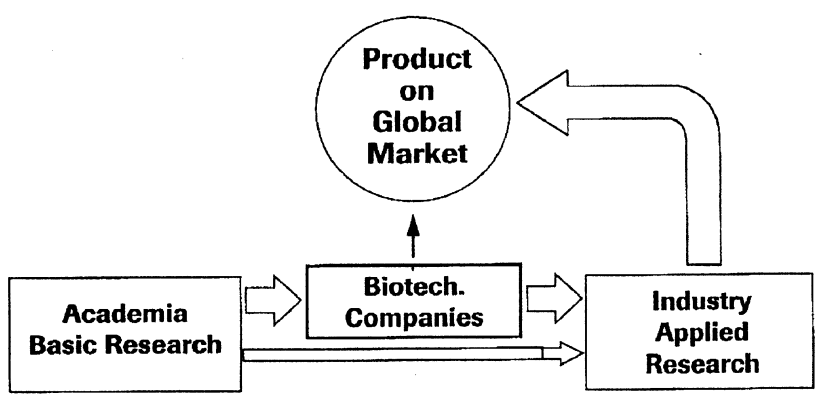

Fig. 7 A model for biomedical innovation based upon basic research.

Table 2 The basic sciences in academe as they are expressed in a societal context

- Prerequisite basic sciences:

- Industrial innovation:

- Main stakeholders in education and basic research:

- Main stakeholders in innovation:

- Biology
- Chemistry
— Mathematics/informatics
— Physics
— Translation of new knowledge into novel products
- Government
- University
- Government
- University
- Industry
- Society

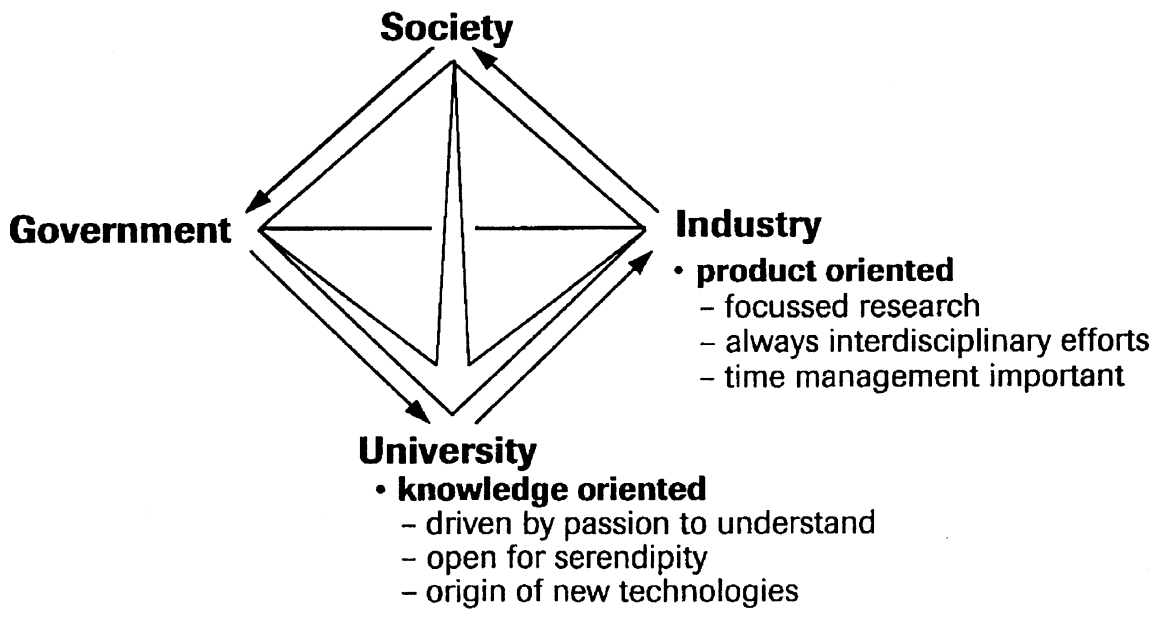

Fig. 8 The relationship among the main stakeholders in innovation.

Table 3 Academic science and the needs of society will become more integrated in the 21 st century

- More opportunities for experimental research

- Expanding overlap between the scientific disciplines

- Rapidly growing complexity

- Autarky of single laboratories disappearing

- Basic research heavily dependent on governmental funding

- University-industry collaborations intensifying

- Increasing impact of sciences on society 
Table 4 Return on investment in biotechnology

\begin{tabular}{llll}
\hline $\begin{array}{l}\text { Funding of biomedical } \\
\text { research by NIH } \\
(10 \% \text { annual interest })\end{array}$ & $\begin{array}{l}\text { Market } \\
\text { capitalization of } \\
\text { US biotech industry }\end{array}$ & $\begin{array}{l}\text { US biotech } \\
\text { revenues }\end{array}$ & $\begin{array}{l}\text { EU biotech } \\
\text { revenues }\end{array}$ \\
\hline $1940-76: \$ 38 \mathrm{bn}$ & $\begin{array}{l}\text { 1995: } \$ 52 \mathrm{bn} \\
1996: \$ 83 \mathrm{bn}\end{array}$ & $\begin{array}{l}1995: \$ 12.7 \mathrm{bn} \\
1996: \$ 14.6 \mathrm{bn}\end{array}$ & \\
& & $1997: \$ \mathrm{bn}$ & $19 \mathrm{bn}$ \\
\hline
\end{tabular}

Sources: [4].

Table 5. Top R \& D spenders 1996/97 (US\$millions)

\begin{tabular}{lcclc}
\hline Company & $\begin{array}{l}\text { Ranking } \\
\text { sales }\end{array}$ & $\begin{array}{l}\text { Pharma } \\
\text { sales }\end{array}$ & $\begin{array}{l}\text { Pharma R\&D } \\
\text { expenditure }\end{array}$ & $\begin{array}{l}\text { R\&D as } \\
\text { \% of sales }\end{array}$ \\
\hline Novartis & 3 & 9858 & 1854 & 18.8 \\
Glaxo Wellcome & 2 & 13027 & 1813 & 13.9 \\
Roche & 10 & 6686 & 1706 & 20.2 \\
Pfizer & 6 & 8188 & 1522 & 15.8 \\
Merck & 1 & 13295 & 1487 & 11.7 \\
Hoechst Marion Roussel & 5 & 8373 & 1487 & 17.2 \\
Pharmacia \& Upjohn & 15 & 5079 & 1266 & 17.6 \\
Lilly & 11 & 6427 & 1189 & 14.7 \\
Bayer & 18 & 4783 & 1154 & 13.9 \\
American home products & 7 & 7457 & 1100 & \\
\hline
\end{tabular}

Source: [5].

Table 6 The international biotechnology industry

$1976 \quad \begin{aligned} & \text { Genentech Inc. founded by } \\ & \text { Robert Swanson, chemist, venture capitalist and } \\ & \text { Herbert Boyer, molecular biologist } \\ & \text { first products envisaged: human insulin } \\ & \text { human growth hormone }\end{aligned}$
19951308 companies with 108000 employees
19961287 companies with 118000 employees
19971274 companies with 140000 employees
1995584 companies with 17200 employees
Europe $\quad 1996716$ companies with 27500 employees
19971036 companies with 39045 employees

Source: [7].

Regarding the majority of countries, and especially developing countries, it is preferable for them to establish their own focussed research models, for instance concentrating efforts on soybeans and sugar cane like in Brazil, corn like in Mexico, and rice like in the Philippines, rather than trying to emulate the science of the USA and a few other developed countries.

Contacts between scientists and society have to be stepped up. This is a matter of urgency. Politically relevant scientific issues have to be discussed with the public at large. It would be very rewarding for a country to have a population with a high level of scientific awareness, perceiving science not as a threat but as an opportunity. 
Finally, a solid education, of which scientific training is an important part, is a key factor for success. Another important factor is a legal framework that allows entrepreneurial activity to flourish. But the basis of all of it is education and, again, education and, once again, education. Or, as Abraham Lincoln (1809-1865, 16th President of the United States) put it, 'If you think education is expensive, try ignorance.'

\section{REFERENCES}

1 PhRMA Annual Survey. US companies, January (1998).

2 M. J. Plunkett, J. A. Ellman. Sci. Am. April, 69-73 (1997).

3 W. A. Warr. J. Chem. Inf. Comput. Sci 134-140 (1997).

4 US Department of Health and Human Services: NIH Almanac (1979), NIH Almanac (1983), NIH Databook (1993); Ernst \& Young: Biotech 97 Alignment, Europ. Life Sci. '98.

5 Script's 1997 pharmaceutical company league table, November (1997).

6 Ernst \& Young. LLP Biotech, 97 Alignment; Ernst \& Young. European Biotech 97; Handelsblatt, 4 May (1998). 